Egyptian J. of Nutrition Vol. XXXVI No. 1 (2021)

\title{
Potential Effects of Sage powder, Sesame and Olive Oils on Lipid Profile and Liver Functions of Non-Alcoholic Fatty Liver Rats.
}

\section{Hadeer Ashraf Abd El-Aziz Abd El-Megeid*, Seham A.M.} Tharwat $^{\star *}$, Sonia S. El-Marasy ${ }^{\star *}$ and Ahmed E. Basyony. ${ }^{\star * *}$

* Graduate student, Nutrition and Food Science Dept. Faculty of Home Economics, Helwan University, Egypt.

${ }^{* *}$ Department of Nutrition and Food Science, Faculty of Home Economics, Helwan University, Egypt.

*** Department of Biochemistry, Food Technology Institute, Egypt.

\begin{abstract}
The aim of this study was to investigate the effects of sage, sesame and olive oils alone and in combination with sage on total lipid ( $T L$ ), total cholesterol (TC), triglyceride (TG), serum lipoprotein fractions (HDL-C, LDL-C and VLDL-C), liver enzymes and antioxidant enzymes, as well as histological changes of liver in obese nonalcoholic fatty liver disease (NAFLD) albino rats. A total of 72 adult male albino rats weighing $(200 \pm 10 \mathrm{~g})$ were used in this study. The rats were divided into two main groups: The first group (8 rats) fed on basal diet (BD) as control negative group (-ve). The second main group (64 rats) fed on high fat diet (HFD) for (8) weeks to induce non-alcoholic fatty liver disease (NLFLD). then rats were divided into (8 subgroups). One (8 rats) fed (HFD), as positive control
\end{abstract}


Hadeer Ashraf Abd El-Aziz Abd El-Megeid, Seham A.M. Tharwat, Sonia S. El-Marasy and Ahmed E. Basyony.

group (+ve). The other (7 subgroups) fed on modified (HFD), one of them by adding $5 \%$ sage. The other sex subgroups were fed on modified high fat diet (MHFD) by replace $20 \%$ sheep tallow (ST) by $20 \%$ sesame oil (SO), $20 \%$ olive oil (OO) and mixed $10 \%$ (SO) with $10 \%(\mathrm{OO})$ without or with sage for (8 weeks). Results revealed that, (MHFD) by adding $5 \%$ sage or by replacing $20 \%$ (ST) to $20 \%$ from (SO), (OO) and $20 \%$ mixed between them (1:1 W/W) without or with $5 \%$ sage induced a significant decrease in serum liver enzymes (Aspartate AminotransferaseAST, Alanin Aminotransferase ALT, and Alkaline phosphates ALP), total cholesterol, triglyceride, LDL-C and VLDL-c, while results revealed a significant increase in HDL-c level. Also results revealed a statistical significant increase in antioxidant enzymes glutathione peroxidase, superoxide dismutase and catalase antioxidants, as compared to the (+ve) control group. Histopathological examination revealed that only (NAFLD) group fed on (MHFD) containing $20 \%$ mixed (SO) with (OO) (1:1 W/W) plus $5 \%$ sage showed the best ameliorates of fatty liver. In conclusion, replacing $20 \%$ from (ST) by $20 \%$ from mixed (SO) with (OO) $(1: 1$ W/W) plus 5\% sage, ranged somewhere between them rise the effects of either component alone and induced the greatest improvement in case of (NAFLD) fed on (HFD).

\section{Introduction}

When we consider the management of Non-Alcoholic Fatty Liver Disease (NAFLD), two aspects should be considered. One is that it 
Egyptian J. of Nutrition Vol. XXXVI No. 1 (2021)

can be a part of the metabolic syndrome. About $80 \%$ of patients with metabolic syndrome have NAFLD (Antunes and Bhimji., 2017). Although the prevalence of NAFLD is $20-40 \%$ in the general population, about 70\% of type 2 diabetes mellitus (Leite et al., 2008), and $85 \%$ of patients with morbid obesity (BMI $\geq 40$ ) have NLFLD (Fabbrini et al., 2009). In the general population, $80 \%$ of patients with NAFLD are overweight and $20 \%$ of NAFLD patients have normal weight as per ultrasonography (Bellentani and Tiribelli, 2001).

As NAFLD is related to insulin resistance, gradual weight loss is extremely important in overweight and obese individuals (Harrison and Day, 2007).About 7-10\% of weight loss over one year by lifestyle changes has been associated with histological improvement in simple steatosis and NASH (Tilg and Moschen, 2010). Diet and moderate aerobic exercise the first line measures to reduce weight and improve insulin resistance (Wilkins et al., 2013). Therefore, study aimed to investigate the effects of sage and sesame \& olive oils alone and in combination with sage on some biochemical parameters and histological changes of liver in obese nonalcoholic fatty liver disease (NAFLD) albino rats.

\section{Materials and Methods}

Material: Casein, vitamins, minerals, cellulose, and choline chloride were purchased from El- Gomhoria Company, Cairo, Egypt. Soy, sesame and olive oils were obtained from Agricultural Research Center, Giza, Egypt. Sage was obtained from the National market of 
Hadeer Ashraf Abd El-Aziz Abd El-Megeid, Seham A.M. Tharwat, Sonia S. El-Marasy and Ahmed E. Basyony.

Agricultural herbs and medicinal plants, Cairo, Egypt. Kits for biochemical analysis were obtained from Alkan for pharmaceutical and chemical Dokki, Egypt.

Rats: Seventy-two adult male albino rats (Spragu Dawley Strain) were purchased from Helwan farm of experimental animals, Ministry of Health and population, Helwan, Cairo, Egypt.

\section{Methods:}

\section{Experimental Design:}

A total of 72 adult male albino rats of Sprague-Dauley Strain weighing $200 \pm 10 \mathrm{~g}$ were used in this study. The rats were divided into two main groups: The first main group $(n=8)$ fed on basal diet $\mathrm{BD}$ and used as a control negative group (-ve). The second main group (64) rats was fed on high fat diet (HFD) containing $20 \%$ sheep tallow for 8 weeks to induce nonalcoholic fatty liver disease (NAFLD) according to (Zarghani et al., 2016).NAFLD rats were divided into (8 subgroups) one of them (8rats) was fed on (HFD), used as a positive control group (+ve). The other (7 subgroups) fed on modified (HFD), one of them by adding $5 \%$ sage. The other six subgroups were fed on modified high fat diet (MHFD) by replacing $20 \%$ sheep tallow (ST) by $20 \%$ sesame oil (SO), $20 \%$ olive oil (OO) and mixed $10 \%$ (SO) with $10 \%(\mathrm{OO})(1: 1 \mathrm{~W} / \mathrm{W})$ without or with $5 \%$ sage for 8 weeks'. At the end of the experiment, rats were sacrificed, liver removed and weighed. Blood samples were collected, left to clot, the serum was separated. 
Egyptian J. of Nutrition Vol. XXXVI No. 1 (2021)

At the end of the experimental period ( 8 weeks). Animals were fasted overweight, and then sacrificed under very light ether an aesthesia - blood samples were collected from hepatic portal vein of each rat. Serum were carefully separated by centrifugation of blood sample. Then kept frozen at $-20^{\circ} \mathrm{C}$ until the analysis. Liver, was removed from rats by careful dissection, washed in saline solution $(0.9 \%)$, dried using filter paper and independently weighed.

\section{Biochemical analysis:}

Determination of total lipids according to Christopher and Ralph, (1970). Triglycerides according to Fossati and prencipe (1982). Total cholesterolAllain et al., (1974). High density lipoprotein cholesterol (HDL-C) (Burstein, 1970).Low and very low density lipoprotein cholesterol (LDL-C and VLDL-C) Friedwald et al., (1972). Aspartate Aminotransferase(AST) and Alanin Aminotransferase (ALT) Henry (1974). Alkaline phosphates (ALP) Belfield and Goldberg (1971).Liver [catalase (CAT), superoxide dismutase (SOD) and reduced glutathione (GSH) activities] were measured according to the methods described by (Aebi, 1984; Beauchamp and Fridovich 1971 and Paglia\& Valentine 1967),respectively.

\section{Histopathological Examination:}

Specimens from liver tissue was taken immediately after sacrificing animals, and fixed in $10 \%$ buffered neutral formalin solution. The fixed specimens were then trimmed, washed and dehydrated imbedded in paraffin, cut in sections of 46 microns' thickness and stained with haematoxylin and eosin stain, according to(Sheehan and Hrapchak, 1980). 
Hadeer Ashraf Abd El-Aziz Abd El-Megeid, Seham A.M. Tharwat, Sonia S. El-Marasy and Ahmed E. Basyony.

\section{Statistical Analysis:}

Results of biochemical analysis and biological evaluation of each group were statistical analyzed, mean, standard error and oneway ANOVA test using SAS package with level of significant $p<0.05$ (SAS,2004).

\section{Results and Discussion}

Effects of Sage, Sesame and Olive Oils on Total Lipids, Cholesterol and Triglycerides in Nonalcoholic Fatty Liver Rats.

Table (1) illustrated the effects of high fat diet (HFD) or modified high fat diet (MHFD) by replacing 20\% sheep tallow (ST) to $20 \%$ (SO), 20\% (OO), 20\% mixed (SO) with (OO) (1:1 W/W) without or with $5 \%$ sage on serum total lipid (TL), total cholesterol (TC) and triglycerides (TG) in Nonalcoholic Fatty Liver Disease (NAFLD) rats. Statistical analysis showed a significant increase $(p \leq .05)$ in $(T L)$, (TC) and (TG) levels in control (+ve) group fed on (HFD), as compared to control (-ve) group fed on basal diet, which agree with (Wu et al., 2013) suggested that (HFD) induced increase serum (TG) and (TC) levels, as compared to those fed on low fat diet (LFD).

Our results revealed that, all groups fed on (MHFD) induced a significant decrease $(p \leq .05)$ in serum (TL), (TC) and (TG). The best decrease recorded for group fed on mixed oils $(10 \%$ SO with $10 \%$ OO) plus $5 \%$ sage. 
Egyptian J. of Nutrition Vol. XXXVI No. 1 (2021)

Olive oil and sesame oil contain high amounts of mono unsaturated fatty acids MUFAs, concerning the effects of MUFAs(Paniagua et al., 2007) demonstrated that, consumption of MUFAs decreased blood (TGs) by increasing fatty acid oxidation through activation of peroxisome proliferator - activated receptor (PPAR) or by reducing the activation of sterol regulatory element binding protein (SREBP) and inhibiting lipogenesis.

Concerning the effects of (SO) on TL, TC and TG, our results are at the same line with (Taha et al., 2014) who reported that, treatment of hyperlipidimic rats with (SO) $5 \& 10 \%$ showed hypolipidimic activity as they decreased hepatic level of TG \& TC. Concerning sage effects on plasma lipids (Eidi and Eidi., 2009) reported that, sage ethanolic extract significantly decreased serum glucose, triglycerides and total cholesterol.

In this respect, (Ben Khedher et al., 2018) suggested that, sage treated animals had a decrease in plasma triglycerides level.

\section{Effects of Sage, Sesame and Olive Oils On Serum Lipoprotein Fraction in Nonalcoholic Fatty Liver Rats.}

Results presented in Table (2) showed the effects of (HFD) and (MHFD) on lipoprotein cholesterol in nonalcoholic fatty liver disease (NAFLD) albino rats. Results revealed that (+ve) control group fed on (HFD) recorded a significant increase in LDL-c and VLDL-C, as compared to the (-ve) control group, while recorded a significant decrease in (HDL-c) level, as compared to the negative control group $(-v e)$ 
Hadeer Ashraf Abd El-Aziz Abd El-Megeid, Seham A.M. Tharwat, Sonia S. El-Marasy and Ahmed E. Basyony.

Also results in table (2) revealed that, all (+ve) groups fed on tested (MHFD) by adding 5\% sage to HFD or replacing (20\% ST) to $20 \%(\mathrm{OO}), 20 \%$ (SO) and mixed (1:1 W/W) from 10\% (SO) with $10 \%$ (OO) without or with $5 \%$ sage induced a significant decrease $(p \leq$ 0.05 )in LDL-c and VLDL-c, while recorded a significant increase ( $p \leq$ $0.05)$ in (HDL-c). However, rats group fed on diet containing $(10 \%$ SO and $10 \%$ OO) plus $5 \%$ sage; After 8 weeks, induced a significant increase in HDL-c, while recorded a significant decrease in LDL-C and VLDL-C.

Our results are in agree with (Christensen et al., 2010) who reported that, sage extract was able to lower plasma cholesterol, low density lipoprotein LDL-C and TGs, as well as increase the high density lipoprotein (HDL-c) levels in lipidemic rats. On the other side our results are at the same line with (Asgary et al., 2013) whoreported that dietary supplementation with sesame oil significantly reduce TC and LDL-C concentration in rabbits under a lipogenic diet. In this concern (EI-Baz et al., 2015) reported that supplementation of hypolipidemic rats with (SO) found to have lower circulating concentration of TC, LDL-C and normalized TG.

Concerning (OO) (Bopitiy and Madhujith., 2013) suggested that olive oil $(\mathrm{OO})$ rich in mono unsaturated fatty acid (MUFA) lower total and LDL-C, triglycerides and increase HDL-C. We suggested that, combination between $(\mathrm{SO})$ with $(\mathrm{OO})$ plus sage maximized the potential effects of each component alone. 
Egyptian J. of Nutrition Vol. XXXVI No. 1 (2021)

Effects of Sage, Sesame and Olive Oils On Liver Enzymes in Nonalcoholic Fatty Liver Rats.

Table (3) showed the effects of (HFD) and (MHFD) on liver enzymes in (NAFLD) albino rats. Results revealed that, serum liver enzymes as spartate amino transferas (AST), Alanin amino transferas (ALT), and alkaline phosphatase (ALP) levels for the control (+ve) group recorded a significant increase $(P \leq 0.05)$, as compared to the control (-ve) group fed on (BD). In this respect(Tolman et al., 2004) reported that, the increased levels of the liver enzymes (ALT), (AST) and $\gamma$ - glutamyl transferase (GGT) are the markers of (NAFLD).

Concerning (+ve) groups fed on (MHFD) by adding $5 \%$ sage or by replacing $20 \%$ (ST) to $20 \%$ (SO), $20 \%$ (OO) and mixed $(1: 1$ W/W) from $10 \%$ (SO) with $10 \%$ (OO) without or with $5 \%$ sage induced a significant decrease $(P \leq 0.05)$ in level of liver enzymes (AST), (ALT) and (ALP). In this respect, (Amin and Hamza, 2005) suggested that, serum AST, ALT and ALP are the enzymes biomarker to monitor the liver structural integrity and damage and aids in the clinical diagnosis of NAFLD and other liver toxicity conditions. Generally, high fat diet increases these enzymes through the induction of oxidative stress in the liver.

Our results revealed that, consumption of modified (HFD) by adding $5 \%$ sage or replacing $20 \%$ (ST) to $20 \%$ (SO), $20 \%$ (OO) or mixed $20 \%(1: 1 \mathrm{~W} / \mathrm{W})$ from (SO) and (OO) without or with $5 \%$ sage induced a significant decrease in serum liver enzymes (AST, ALT and ALP). 
Hadeer Ashraf Abd El-Aziz Abd El-Megeid, Seham A.M. Tharwat, Sonia S. El-Marasy and Ahmed E. Basyony.

Son et al., (2007)reported that sage leaf extract increased significantly the plasma level of anti-inflammatory cytokines and inhibited an opposite effect on pro inflammatory cytokines by decreasing plasma level of TNF- $\alpha, \mathrm{KC} / \mathrm{GRO}$ and IL-2. KC/GRO is highly induced by pro inflammatory cytokines such as TNF- $\alpha$.

In this respect (El-saher, 2012) reported that, sage and its isolated oils are largely responsible for promoting energy expenditure and fat oxidation, which may led to body weight reduction.

Our results revealed that the best results induced by replacing $20 \%$ (ST) to $20 \%$ mixed (1:1 W/W) $10 \%$ (SO) with $10 \%$ (OO) plus $5 \%$ sage. High amount of sesamin and sesamol have been identified in sesame and they are reported to increase the hepatic mitochondria and peroxisome fatty oxidation rate, also sesame lignans have antioxidant and healthy promoting activity (Uthandi and Ramasamy 2011). In this concern (Kumar and Singh, 2015)reported that, sesame oil has a higher concentration of sesamol, the isolated lignans and sesamol is the best antioxidant and free radical scavenging properties, responsible for the protective response.

Concerning olive oil effects (Shidfar et al., 2018)reported that,the consumption of low caloric diet enriched with olive oil, along with slight weight reduction, reinforces the desired effect of weight loss in improving the levels of hepatic enzymes. 
Egyptian J. of Nutrition Vol. XXXVI No. 1 (2021)

Effects of Sage, Sesame and Olive Oils on Antioxidant Enzymes in Nonalcoholic Fatty Liver Rats.

Table (4) showed the levels of antioxidant enzymes in (NAFLD) fed on (HFD) and (+ve) group fed on (MHFD). Results revealed that, the (+ve) control group recorded a significant decrease $(P \leq 0.05)$ in levels of glutathione peroxidase (GSH-PX), Superoxide dismutase (SOD) and Catalase (CAT) as compared to the control (ve) group.

On the other hand, results revealed that all (+ve) groups fed on tested (MHFD) by adding 5\% sage to HFD, or replacing $20 \%$ (ST) to $(20 \%$ SO or $20 \%$ OO) and mixed $20 \%(1: 1 \mathrm{~W} / \mathrm{W})$ from $10 \%$ (SO) with $10 \%(\mathrm{OO})$ without or with $5 \%$ sage, statistically showed a significant increase $(P \leq 0.05)$ in (GSH-PX), (SOD) and (CAT) levels as compared to the (+ve) control group.

The best results induced greatest increase in (GSH-PX), (SOD) \& (CAT) by (+ve) group (NAFLD) fed on (MHFD) by replacing $20 \%$ (ST) to $20 \%$ mixed $(1: 1 \mathrm{~W} / \mathrm{W})$ from $10 \%$ (SO) with $10 \%$ (OO) plus $5 \%$ sage.

Our results revealed that, in (NAFLD) replacing $20 \%$ (ST) to mixed combination from $10 \%(\mathrm{SO})$ with $10 \%(\mathrm{OO})$ plus $5 \%$ sage, this combination maximized the potential effects of $(\mathrm{OO}),(\mathrm{SO})$, and sage than the potential effect of each component only. 
Hadeer Ashraf Abd El-Aziz Abd El-Megeid, Seham A.M. Tharwat, Sonia S. El-Marasy and Ahmed E. Basyony.

In this concern our results are at a harmony with (Gorinstein et al., 2002) who suggested that, olive oil maintained the plasma lipid pool by regulating the lipid peroxidation and antioxidant parameters. Our results are at the same line with (Hassanein, 2010) who reported that sesame oil contained powerful antioxidant lignans, when mixed with individual sunflower and olive oil generally, the antioxidative stability of oil mixtures was increased.

In this respect Kumar and Singh (2015) suggested that, sesame seeds are rich in phytochemical called lignans, which are methylene dioxyphenyl compounds.

In this concern also our results are at a harmony with (Alshubaily and Jambi, 2018)who reported that, sage water extract could be used as a natural antioxidant supplement due to the presence of essential oil, phenolic contents and other antioxidant components in sage.

Effects of Sage, Sesame and Olive Oils on Liver Histopathological Changes in Nonalcoholic Fatty Liver Rats.

Histopathological examination of liver of rats from control (-ve) group fed on (BD) revealed that normal histology of hepatic lobule as shown in Photo (1\&2). On the other side. In rats from (+ve) control group fed on (HFD), showed a macrovesicular steatosis of hepatocytes (Photo 3\&4).

Concerning (+ve) groups (NAFLD) fed on (MHFD) for 8 weeks by adding $5 \%$ sage to HFD, showed vacuolar degeneration of 
Egyptian J. of Nutrition Vol. XXXVI No. 1 (2021)

hepatocytes as shown in Photo (5\&6). Some Sections from (+ve) group fed on (MHFD) by replacing $20 \%$ (ST) to $20 \%$ (OO) revealed cytoplasmic vacuolization of hepatocytes as shown in Photo (7\&8).

Meanwhile examination of liver from (+ve) group fed on (MHFD) by replacing $20 \%$ (ST) to $20 \%$ sesame oil (SO), microscopically sections of liver revealed hydropic degeneration of hepatocytes as shown in Photo (9\&10). Meanwhile liver sections examination of rats from (+ve) group fed on (MHFD) by replacing $20 \%$ (ST) to $20 \%$ from mixed (1:1 W/W) $10 \%$ (SO) plus $10 \%$ (OO), revealed cytoplasmic vacuolization of hepatocytes and slight hydropic degeneration as shown in Photo (11\&12).

On the other hand, our histopathological results of liver sections examination from (+ve) group fed on modified (HFD) by replacing $20 \%$ (ST) to mixed (1:1 W/W) from $10 \%$ (SO) with $10 \%$ (OO) plus $5 \%$ sage showed slight hydropic degeneration of hepatocytes as shown in Photo (13 \&14).

Results of the histopathological examination of liver of (NAFLD) fed on (MHFD) by adding $5 \%$ sage or replacing $20 \%$ (ST) to $20 \%$ (SO), (OO) and 20\% from mixed (1:1 W/W) without or with $5 \%$ sage different (MHFD) dose revealed a dose dependent reduction of steatosis degenerative changes caused by (HFD). This histological finding may confirm the various biochemical changes in lipid profile, TC, TG and lipid fraction. These findings at a harmony with (Szende et al., 1994) who suggested that olive oil, in contrast to polyunsaturated oils, could protect the liver against the development of fibrosis. 
Hadeer Ashraf Abd El-Aziz Abd El-Megeid, Seham A.M. Tharwat, Sonia S. El-Marasy and Ahmed E. Basyony.

In respect to the effect of sesame oil (Bopitiy and Madhujith, 2013) suggested that (SO) possessed a strong antioxidant activity. On the other side (Alves Rodrigies et al., 2011) cleared that hydroalcoholic extract and active compound isolated from sage such as carnosol, oleanolic and ursolic acids reduces the nociception and oedema induced by different chemicals.

In this concern Oniga et al, (2007) demonstrated that sage leaf extract increased significantly the plasma level of antiinflammatory cytokines and exhibited an opposite effect on proinflammatory cytokines by decreasing the plasma level of TNF-X, $\mathrm{KC}$ / GRO and IL-12, KC/GRO is highly induced by pro-inflammatory cytokines such as TNF- $\alpha$ (Son et al., 2007).

\section{Conclusion}

our results revealed that modified high fat diet (MHFD) by replacing $20 \%$ (ST) to $20 \%$ from a combination between mixed $(1: 1$ W/W) $10 \%$ (SO) with $10 \%$ (OO) plus $5 \%$ sage induced a clear raise in the protective effects of either component alone in the amelioration of liver (NAFLD) and prevent fibrosis or cirrhosis. This results confirmed by histopathological examination. 
Egyptian J. of Nutrition Vol. XXXVI No. 1 (2021)

Table (1): Effects of Sage, Sesame and Olive Oils on Total Lipids, Cholesterol and Triglycerides in Nonalcoholic Fatty Liver Rats.

\begin{tabular}{|c|c|c|c|c|}
\hline \multicolumn{2}{|c|}{ Parameters } & Lipid & Cholesterol & Triglycerides \\
\hline \multicolumn{2}{|c|}{ Groups } & \multicolumn{3}{|c|}{$\mathrm{mg} / \mathrm{dl}$} \\
\hline \multicolumn{2}{|c|}{ Control (-ve) group } & $\begin{array}{l}303.628^{h} \\
+5.328\end{array}$ & $\begin{array}{l}88.556^{h} \\
+3216\end{array}$ & $\begin{array}{l}56.030^{\mathrm{g}} \\
+3420\end{array}$ \\
\hline \multicolumn{2}{|c|}{$\begin{array}{l}\text { Control (+ve) group, fed on high fat diet } \\
\text { (HFD). }\end{array}$} & $\begin{array}{l}518.758^{\mathrm{a}} \\
\pm 6.948\end{array}$ & $\begin{array}{l}166.433^{\mathrm{a}} \\
\pm 8.742\end{array}$ & $\begin{array}{l}107.645^{\mathrm{a}} \\
\pm 8.400\end{array}$ \\
\hline \multirow{7}{*}{ 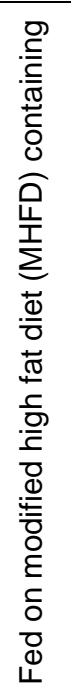 } & $5 \%$ sage & $\begin{array}{l}471.367^{\mathrm{b}} \\
\pm 6.859\end{array}$ & $\begin{array}{l}149.612^{b} \\
\pm 5.547\end{array}$ & $\begin{array}{l}98.225^{b} \\
\pm 8.872\end{array}$ \\
\hline & 20\% olive oil "OO" & $\begin{array}{l}401.539^{d} \\
\pm 9.552\end{array}$ & $\begin{array}{l}142.915^{\mathrm{c}} \\
\pm 5.547\end{array}$ & $\begin{array}{l}92.121^{b c} \\
\pm 5.152\end{array}$ \\
\hline & $20 \%$ sesame oil "SO" & $\begin{array}{l}440.104^{c} \\
\pm 5.810\end{array}$ & $\begin{array}{c}139.536^{\text {cd }} \\
\pm 4.516\end{array}$ & $\begin{array}{l}86.163^{\mathrm{cd}} \\
\pm 3.4534\end{array}$ \\
\hline & $10 \%$ OO plus $10 \%$ SO & $\begin{array}{l}393.939^{d} \\
\pm 9.470\end{array}$ & $\begin{array}{l}135.015^{d} \\
\pm 3.748\end{array}$ & $\begin{array}{l}83.660^{d} \\
\pm 3.243\end{array}$ \\
\hline & $20 \%$ OO plus $5 \%$ sage & $\begin{array}{l}361.245^{f} \\
\pm 10.604\end{array}$ & $\begin{array}{l}128.208^{\mathrm{e}} \\
\pm 3.472\end{array}$ & $\begin{array}{l}79.324^{\mathrm{de}} \\
\pm 3.517\end{array}$ \\
\hline & $20 \%$ SO plus $5 \%$ sage & $\begin{array}{l}378.286^{\mathrm{e}} \\
\pm 7.732\end{array}$ & $\begin{array}{l}119.539^{f} \\
\pm 3.553\end{array}$ & $\begin{array}{l}73.576^{\mathrm{e}} \\
\pm 3.067\end{array}$ \\
\hline & $\begin{array}{l}10 \% \text { OO plus } 10 \% \text { SO plus } 5 \% \\
\text { sage }\end{array}$ & $\begin{array}{l}348.0399 \\
\pm 6.320\end{array}$ & $\begin{array}{l}111.500^{g} \\
\pm 3.086\end{array}$ & $\begin{array}{l}66.357^{f} \\
\pm 3.725\end{array}$ \\
\hline
\end{tabular}

OO: Olive Oil SO: Sesame Oil

Mean values in each column with same letters are not significantly different.

LSD: Least significant differences $(P<0.05)$ 
Hadeer Ashraf Abd El-Aziz Abd El-Megeid, Seham A.M. Tharwat, Sonia S. El-Marasy and Ahmed E. Basyony.

Table (2): Effects of Sage, Sesame and Olive Oils on Serum Lipoprotein Cholesterol in Nonalcoholic Fatty Liver Rats.

\begin{tabular}{|c|c|c|c|c|}
\hline \multicolumn{2}{|c|}{ Groups $\quad$ Parameters } & $\begin{array}{l}\mathrm{HDL}-\mathrm{c} \\
\mathrm{mg} / \mathrm{dl}\end{array}$ & $\begin{array}{l}\text { LDL-c } \\
\mathrm{mg} / \mathrm{dl}\end{array}$ & $\begin{array}{l}\text { VLDL-c } \\
\mathrm{mg} / \mathrm{dl}\end{array}$ \\
\hline \multirow{2}{*}{\multicolumn{2}{|c|}{ Control (-ve) group }} & $51.849^{\mathrm{a}}$ & $25.500^{i}$ & $11.205^{\mathrm{g}}$ \\
\hline & & \pm 1.938 & \pm 0.780 & \pm 0.684 \\
\hline \multirow{2}{*}{\multicolumn{2}{|c|}{$\begin{array}{l}\text { Control (+ve) group, fed on high fat diet } \\
\text { (HFD). }\end{array}$}} & $25.876^{h}$ & $119.029^{a}$ & $21.528^{a}$ \\
\hline & & \pm 3.890 & \pm 3.263 & \pm 1.679 \\
\hline \multirow{4}{*}{ 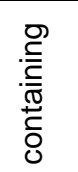 } & \multirow{2}{*}{$5 \%$ sage } & $29.160^{g}$ & $100.986^{b}$ & $19.644^{b}$ \\
\hline & & \pm 3.214 & \pm 1.753 & \pm 1.774 \\
\hline & \multirow{2}{*}{$20 \%$ olive oil "OO" } & $32.491^{f}$ & $92.000^{\mathrm{c}}$ & $18.424^{b c}$ \\
\hline & & \pm 1.945 & \pm 3.068 & \pm 1.030 \\
\hline \multirow{4}{*}{ 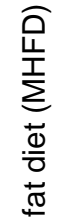 } & \multirow{2}{*}{ 20\% sesame oil "SO" } & $34.899^{\text {ef }}$ & $87.403^{d}$ & $17.232^{\mathrm{cd}}$ \\
\hline & & \pm 1.535 & \pm 3.195 & \pm 0.690 \\
\hline & \multirow{2}{*}{ with $10 \%$ OO plus $10 \%$ SO } & $37.062^{\mathrm{e}}$ & $81.221^{\mathrm{e}}$ & $16.731^{\mathrm{d}}$ \\
\hline & & \pm 1.526 & \pm 3.041 & \pm 0.648 \\
\hline \multirow{6}{*}{ 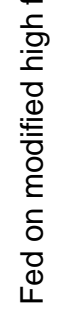 } & \multirow{2}{*}{$20 \%$ OO plus $5 \%$ sage } & $40.703^{d}$ & $71.639^{f}$ & $15.864^{\text {de }}$ \\
\hline & & \pm 1.094 & \pm 2.930 & \pm 0.703 \\
\hline & \multirow{2}{*}{$20 \%$ SO plus $5 \%$ sage } & $43.624^{c}$ & $61.199 \mathrm{~g}$ & $14.715^{\mathrm{e}}$ \\
\hline & & \pm 1.237 & \pm 3.724 & \pm 0.613 \\
\hline & \multirow{2}{*}{$10 \%$ OO plus $10 \%$ SO plus $5 \%$ sage } & $47.795^{b}$ & $50.433^{h}$ & $13.271^{f}$ \\
\hline & & \pm 0.842 & \pm 3.169 & \pm 0.745 \\
\hline
\end{tabular}

Mean values in each column with same letters are not significantly different.

LSD: Least significant differences $(P<0.05)$ 
Egyptian J. of Nutrition Vol. XXXVI No. 1 (2021)

Table (3): Effects of Sage, Sesame and Olive Oils On Liver Enzymes in Nonalcoholic Fatty Liver Rats.

\begin{tabular}{|c|c|c|c|c|}
\hline \multicolumn{2}{|c|}{$\begin{array}{ll}\text { Groups } & \text { Parameters } \\
\end{array}$} & $\begin{array}{c}\text { AST } \\
\text { U/l }\end{array}$ & $\begin{array}{c}\mathrm{ALT} \\
\mathrm{U} / \mathrm{I}\end{array}$ & $\begin{array}{l}\mathrm{ALP} \\
\mathrm{U} / \mathrm{I}\end{array}$ \\
\hline \multicolumn{2}{|c|}{ Control (-ve) group } & $\begin{array}{l}74.614^{\mathrm{fg}} \\
\pm 2.893\end{array}$ & $\begin{array}{l}25.468^{h} \\
\pm 1.535\end{array}$ & $\begin{array}{l}101.694^{9} \\
\pm 6.469^{9}\end{array}$ \\
\hline \multicolumn{2}{|c|}{$\begin{array}{l}\text { Control (+ve) group, fed on high fat diet } \\
\text { (HFD). }\end{array}$} & $\begin{array}{l}116.056^{\mathrm{a}} \\
\pm 4.682\end{array}$ & $\begin{array}{l}81.323^{a} \\
\pm 3.243\end{array}$ & $\begin{array}{l}277.225^{a} \\
\pm 13.360\end{array}$ \\
\hline \multirow{7}{*}{ 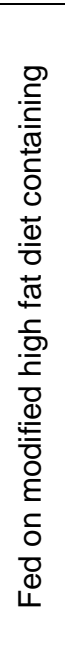 } & $5 \%$ sage & $\begin{array}{l}103.252^{b} \\
\pm 4.262\end{array}$ & $\begin{array}{l}72.971^{b} \\
\pm 3.221^{b}\end{array}$ & $\begin{array}{l}223.805^{b} \\
\pm 7.245\end{array}$ \\
\hline & $20 \%$ olive oil "OO" & $\begin{array}{l}96.822^{c} \\
\pm 4.214\end{array}$ & $\begin{array}{l}67.180^{\mathrm{c}} \\
\pm 3.045\end{array}$ & $\begin{array}{l}218.792^{\text {bc }} \\
\pm 6.677\end{array}$ \\
\hline & $20 \%$ sesame oil "SO" & $\begin{array}{l}92.741^{\mathrm{c}} \\
\pm 2.918\end{array}$ & $\begin{array}{l}62.334^{d} \\
\pm 2.057\end{array}$ & $\begin{array}{l}215.644^{\text {bc }} \\
\pm 4.218\end{array}$ \\
\hline & $10 \%$ OO plus $10 \%$ SO & $\begin{array}{l}86.399^{d} \\
\pm 3.555\end{array}$ & $\begin{array}{l}59.306^{d} \\
\pm 2.452\end{array}$ & $\begin{array}{l}210.032^{\mathrm{c}} \\
\pm 4.640\end{array}$ \\
\hline & $20 \%$ OO plus $5 \%$ sage & $\begin{array}{l}79.922^{\mathrm{e}} \\
\pm 2.919\end{array}$ & $\begin{array}{l}54.060^{e} \\
\pm 2.824\end{array}$ & $\begin{array}{l}196.865^{\mathrm{d}} \\
\pm 4.389\end{array}$ \\
\hline & $20 \%$ SO plus $5 \%$ sage & $\begin{array}{l}75.331^{\text {ef }} \\
\pm 3.369\end{array}$ & $\begin{array}{l}48.590^{f} \\
\pm 3.146\end{array}$ & $\begin{array}{l}183.951^{\mathrm{e}} \\
\pm 5.160^{0}\end{array}$ \\
\hline & $10 \%$ OO plus $10 \%$ SO plus $5 \%$ sage & $\begin{array}{l}70.224 \mathrm{gf}^{\mathrm{f}} \\
\pm 3.548\end{array}$ & $\begin{array}{l}42.686^{g} \\
\pm 2.333\end{array}$ & $\begin{array}{l}174.608^{f} \\
\pm 4.628\end{array}$ \\
\hline
\end{tabular}

OO: Olive Oil SO: Sesame Oil

Mean values in each column with same letters are not significantly different.

LSD: Least significant differences $(P<0.05)$ 
Hadeer Ashraf Abd El-Aziz Abd El-Megeid, Seham A.M. Tharwat, Sonia S. El-Marasy and Ahmed E. Basyony.

Table (4): Effects of Sage, Sesame and Olive Oils on Antioxidant Enzymes in Nonalcoholic Fatty Liver Rats.

\begin{tabular}{|c|c|c|c|c|}
\hline \multicolumn{2}{|c|}{ Groups } & $\begin{array}{c}\text { Glutathione } \\
\text { peroxidase } \\
\text { (GSH-Px) } \\
\text { ng/g Liver }\end{array}$ & $\begin{array}{c}\text { Superoxide } \\
\text { dismutase (SOD) } \\
\text { U/g liver }\end{array}$ & $\begin{array}{c}\text { Catalase (CAT) } \\
\mathrm{mmol} / \mathrm{g} \text { liver }\end{array}$ \\
\hline \multicolumn{2}{|c|}{ Control (-ve) group } & $\begin{array}{l}0.560^{a} \\
\pm 0.012\end{array}$ & $\begin{array}{c}0.392^{\mathrm{a}} \\
\pm 0.0251\end{array}$ & $\begin{array}{r}0.413^{a} \\
\pm 0.016\end{array}$ \\
\hline \multicolumn{2}{|c|}{$\begin{array}{l}\text { Control (+ve) group, fed on } \\
\text { high fat diet (HFD). }\end{array}$} & $\begin{array}{l}0.252^{f} \\
\pm 0.011\end{array}$ & $\begin{array}{r}0.258^{g} \\
\pm 0.011\end{array}$ & $\begin{array}{l}0.210^{f} \\
\pm 0.015\end{array}$ \\
\hline \multirow{7}{*}{ 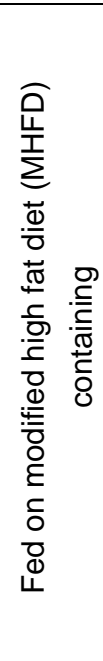 } & $5 \%$ sage & $\begin{array}{l}0.325^{\mathrm{e}} \\
\pm 0.014\end{array}$ & $\begin{array}{l}0.303^{f} \\
\pm 0.009\end{array}$ & $\begin{array}{l}0.265^{\mathrm{e}} \\
\pm 0.011\end{array}$ \\
\hline & $20 \%$ olive oil "OO" & $\begin{array}{l}0.372^{d} \\
\pm 0.014\end{array}$ & $\begin{array}{l}0.326^{\mathrm{e}} \\
\pm 0.009\end{array}$ & $\begin{array}{l}0.290^{d} \\
\pm 0.014\end{array}$ \\
\hline & $\begin{array}{l}20 \% \text { sesame oil } \\
\text { "SO" }\end{array}$ & $\begin{array}{l}0.364^{d} \\
\pm 0.006\end{array}$ & $\begin{array}{l}0.326^{d e} \\
\pm 0.008\end{array}$ & $\begin{array}{l}0.283^{\text {de }} \\
\pm 0.010\end{array}$ \\
\hline & $\begin{array}{l}10 \% \text { OO plus } 10 \% \\
\text { so }\end{array}$ & $\begin{array}{r}0.378^{d} \\
\pm 0.008\end{array}$ & $\begin{array}{l}0.332^{\text {cde }} \\
\pm 0.009\end{array}$ & $\begin{array}{l}0.299^{d} \\
\pm 0.024\end{array}$ \\
\hline & $\begin{array}{l}20 \% \text { OO plus } 5 \% \\
\text { sage }\end{array}$ & $\begin{array}{l}0.439^{c} \\
\pm 0.011\end{array}$ & $\begin{array}{l}0.347^{c} \\
\pm 0.009\end{array}$ & $\begin{array}{l}0.332^{c} \\
\pm 0.008\end{array}$ \\
\hline & $\begin{array}{l}20 \% \text { SO plus } 5 \% \\
\text { sage }\end{array}$ & $\begin{array}{l}0.429^{c} \\
\pm 0.009\end{array}$ & $\begin{array}{l}0.342^{c d} \\
\pm 0.005\end{array}$ & $\begin{array}{l}0.324^{c} \\
\pm 0.006\end{array}$ \\
\hline & $\begin{array}{l}10 \% \text { OO plus } 10 \% \\
\text { so plus } 5 \% \text { sage }\end{array}$ & $\begin{array}{l}0.476^{b} \\
\pm 0.012\end{array}$ & $\begin{array}{l}0.366^{\mathrm{b}} \\
\pm 0.008\end{array}$ & $\begin{array}{l}0.354^{b} \\
\pm 0.008\end{array}$ \\
\hline
\end{tabular}

OO: Olive Oil SO: Sesame Oil

Mean values in each column with same letters are not significantly different. LSD: Least significant differences $(P<0.05)$ 
Egyptian J. of Nutrition Vol. XXXVI No. 1 (2021)

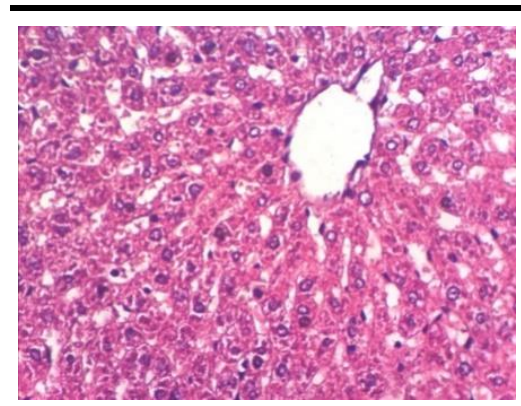

Photo (1):

Liver of rat from group 1showing the normal histological structure of hepatic parenchyma (H \& E X 400).

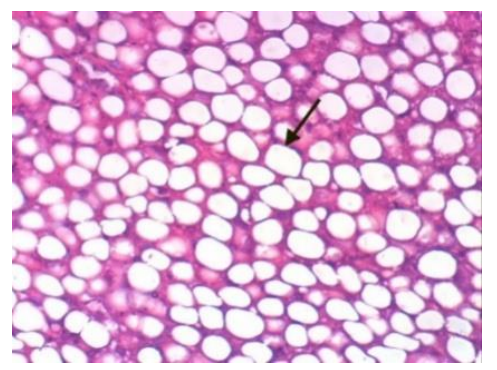

Photo (3):

Liver of rat from group 2showing macrovesicular steatosis of hepatocytes (arrow) (H \& E X 400)

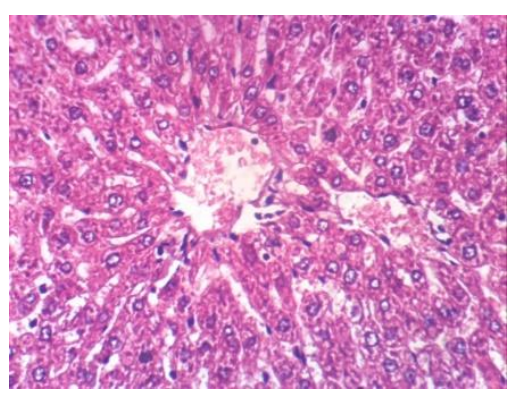

\section{Photo (2):}

Liver of rat from group 1 showing the normal histological structure of hepatic parenchyma (H \& E X 400).

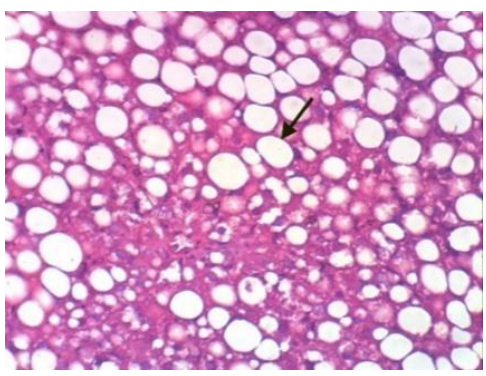

Photo (4):

Liver of rat from group 2 showingmacrovesicular steatosis of hepatocytes (arrow) (H \& E X 400). 
Hadeer Ashraf Abd El-Aziz Abd El-Megeid, Seham A.M. Tharwat, Sonia S. El-Marasy and Ahmed E. Basyony.

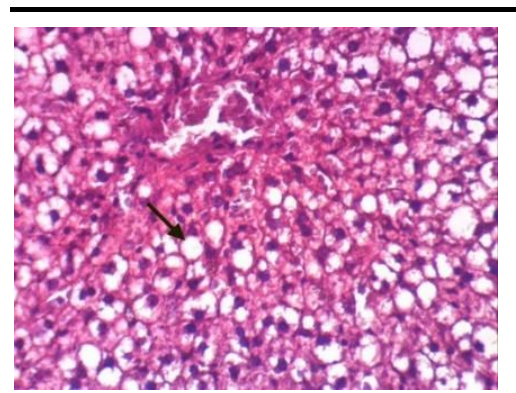

Photo (5):

Liver of rat from group 3 showing vacuolar degeneration of hepatocytes (H\& E X 400).

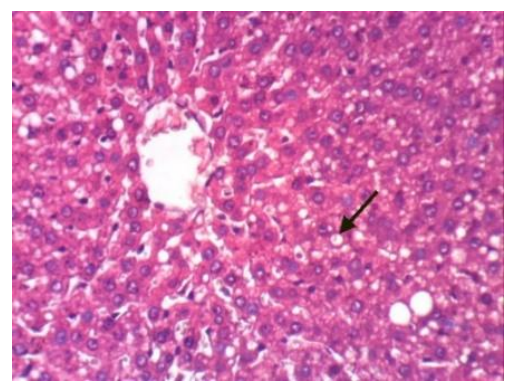

Photo (7):

Liver of rat from group 4 showing cytoplasmic vacuolization of hepatocytes (H \& EX 400).

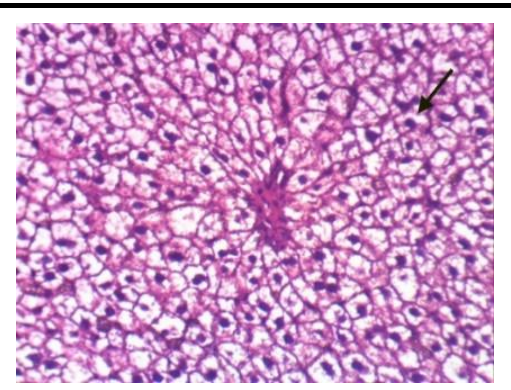

Photo (6):

Liver of rat from group 3 showing hydropic degeneration of hepatocytes

(H\& EX 400)

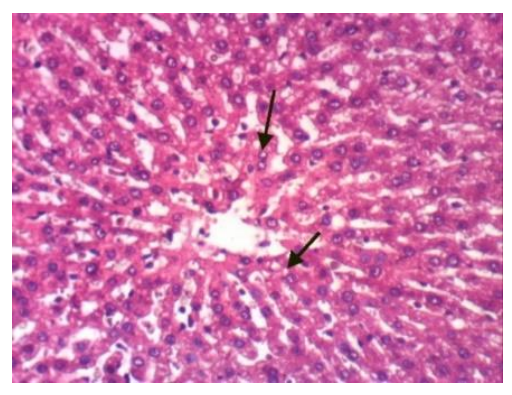

Photo (8):

Liver of rat from group 4 showing cytoplasmic vacuolization of hepatocytes ( $H \& E X 400)$. 
Egyptian J. of Nutrition Vol. XXXVI No. 1 (2021)

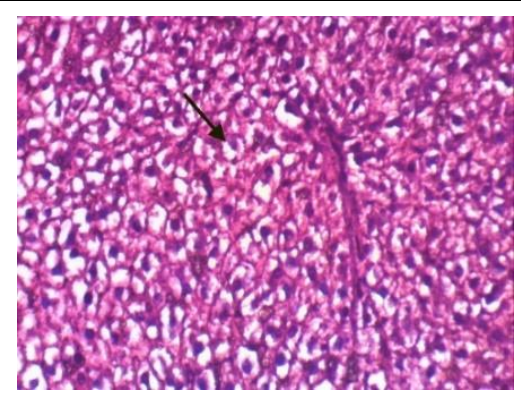

Photo (9):

Liver of rat from group 5 showing hydropic degeneration of hepatocytes

( $H$ \& $E X 400)$.

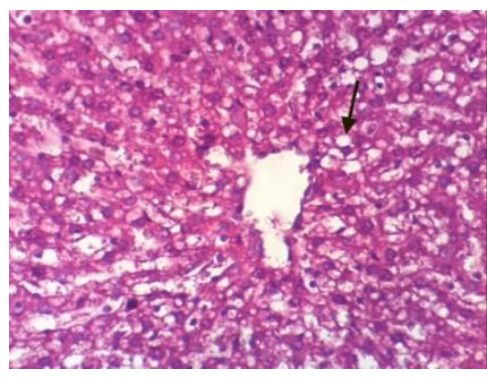

Photo (11):

Liver of rat from group 6 showing cytoplasmic vacuolization of hepatocytes (H\& EX 400).

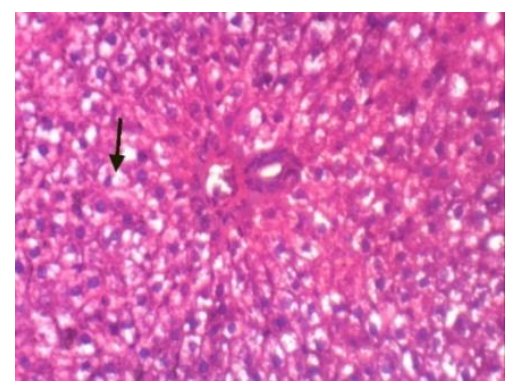

Photo (10):

Liver of rat from group 5 showing hydropic degeneration of hepatocytes (H\& EX 400).

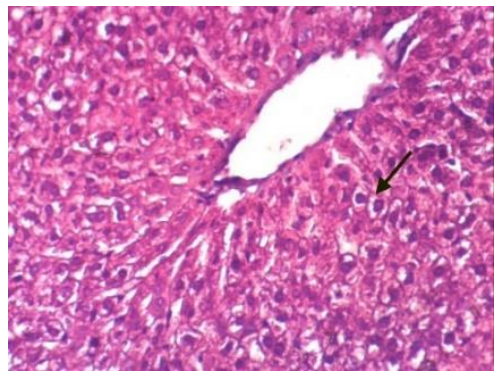

\section{Photo (12):}

Liver of rat from group 6 showing slight hydropic degeneration of hepatocytes (H\& EX 400). 
Hadeer Ashraf Abd El-Aziz Abd El-Megeid, Seham A.M. Tharwat, Sonia S. El-Marasy and Ahmed E. Basyony.

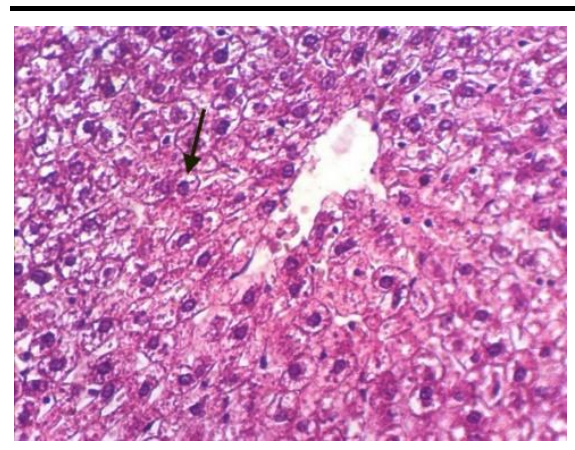

Photo (13):

Liver of rat from group 9 showing slight hydropic degeneration of hepatocytes (H \& E X 400).

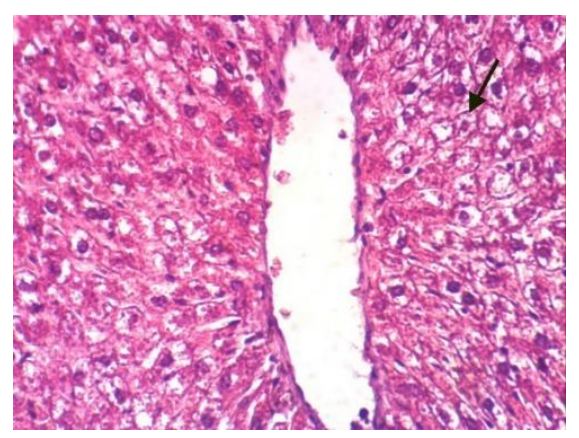

\section{Photo (14):}

Liver of rat from group 9 showing slight hydropic degeneration of hepatocytes (H \& E X 400). 
Egyptian J. of Nutrition Vol. XXXVI No. 1 (2021)

\section{References}

Aebi, H.E. (1984).

Catalse in vitro. Methods in Enzymology, 105:121-126.

Allain, C.Z.; Poon, L.S. and Chan, C.S. (1974):

Enzymatic determination of total serum cholesterol. Clin. Chem., 20: $470-475$.

Alshubaily, F.A. and Jambi, E.J. (2018).

The possible protective effect of sage (Salvia Officinalis L.) water extract against testes and heart tissue damages of hypercholesterolemic rats. International J. of Pharmaceutical and Phytopharmacological Research., 8: 62-68.

Alves Rodrigues, M.R.; Kanazawa, L.K.S.; das Neves, T.L.M.; Silva, C.F.; Horst, H.; Baggio, C.H. and Paula Werne, M.F. (2011).

Antinociceptive and anti-inflammatory potential of extract and isolatedcompounds from the leaves of Salvia officinalis in mice. Journal of Ethnopharmacology 139, (2): 519- 526.

Amin, A. and Hamza, A.A. (2005).

Hepatoprotective effects of hibiscus, rosmarinus and salvia on azathioprine-induced toxicity in rats. Life Sciences, 77(3): 266-278.

Antunes, S. and Bhimji, S. (2017).

Fatty liver. Stat Pearls [Internet].Treasure Island (FL): Stat Pearls publishing., PMID: 28723021. 
Hadeer Ashraf Abd El-Aziz Abd El-Megeid, Seham A.M. Tharwat, Sonia S. El-Marasy and Ahmed E. Basyony.

Asgary, S.; Rafieian-Kopaei,M.; Najafi,S.; Heidarian, E. and Sahebkar, A. (2013).

Antihyperlipidemic effects of sesamum indicum I. in rabbits fed a high-fat diet. The ScientificWorld Journal, Article ID 365892, 5 pageshttp://dx.doi.org/10.1155/2013/365892

Beauchamp, C. and Fridovich, I. (1971).

Superoxide dismutase: Improved assays and an assay applicable to acrylamide gels. Anal. Biochem., 44: 276-287.

Belfield, A. and Goldberg, D.M. (1971):

Normal Ranges and Diagnostic value of serum 5 Nucleotidase and Alkaline phosphatase Activities in infancy. Arch Dis Child; 46: 842 - 846.

Bellentani, S. and Tiribelli, C. (2001).

The spectrum of liver disease in the general population: lesson from the Dionysos study. Journal of Hepatology 35 (4) $531-537$

Ben Khedher, M.R.; Hammami, M.; Arch, S.R.J.; Hislop, C.D.; Eze,D.; Wargent,T.E.; Kępczyńska,A.M. and Zaibi, S.M. (2018).

Preventive effects of Salvia officinalis leaf extract on insulin resistance and inflammation in a model of high fat dietinduced obesity in mice that responds to rosiglitazone.Peer $\mathrm{J}$, 6: e4166 
Egyptian J. of Nutrition Vol. XXXVI No. 1 (2021)

Bopitiy, D. and Madhujith, T. (2013).

Antioxidant activity and total phenolic content of sesame (Sesamum indicum L.) seed oil. Tropical Agricultural Research 24 (3): 296 - 302.

Burstein, M. (1970):

HDL Cholesterol determination after separation high density lipoprotein. Lipid Res., 11: 583.

Christensen, K.B.; Jorgenson, M.; Kotowska, D.; Peterson, R.K.; Kristiansen, K. and Christensen, L.P. (2010).

Activation of the nuclear receptor PPARY by metabolites isolated from sage (Salvia officinalis L.). J. Ethnopharmacol.;132:127-33.

Christopher, S. Frings and Ralph, T. Dunn (1970).

A Colorimetric Method for Determination of Total Serum Lipids Based on the Sulfo-phospho-vanillin Reaction .American Journal of Clinical Pathology, 53(1): 89-91.

Eidi, A. and Eidi, M. (2009).

Antidiabetic effects of sage (Salvia officinalis L.) leaves in normal and streptozotocin-induced diabetic rats. Diabetes \& Metabolic Syndrome: Clinical Research \&Rewviews, 3 (1): 4044.

El-Baz,K.F.; Salama, A.Z.; Aly, F.H. and Taie, A.H. (2015). Potency of sesame oil as antihypercholesterolemic agent in rats fed high-fat diet.Int J. Pharm Bio Sci; 6 (3): (B) 177 189. 
Hadeer Ashraf Abd El-Aziz Abd El-Megeid, Seham A.M. Tharwat, Sonia S. El-Marasy and Ahmed E. Basyony.

El-saher, E.G.E. (2012).

Effect of using herbal mixture extract and camellia sinensis on weight loss in over weight and obese humans as therapy for obesity. J.Am.Sci.,8: 51-60.

Fabbrini, E.; Sullivan, S. and Klein, S. (2009).

Obesity and nonalcoholic fatty liver disease: Biochemical, metabolic, and clinical implications. Hepatology., 51 (2): 679689.

Fossati, P.C. and penciple, L. (1982):

Enzymatic colorimetric determination of total serum triglyceride. Clin. Chem., 28: 2027.

FriedWald, W.T.; Levy, R.I and Fredrickson, D.S. (1972):

Estimation of concentration of low density lipoprotein separated by three different methods.Clin.Chem.,18:499 502.

Gorinstein, S., Leontowicz, H., Lojek, A., Leontowicz, M., Ciz, M., Krzeminski, R., et al. (2002).

Olive Oils Improve Lipid Metabolism and Increase Antioxidant Potential in Rats Fed Diets Containing Cholesterol. Journal of Agricultural and Food Chemistry, 50, 6102-6108. 
Egyptian J. of Nutrition Vol. XXXVI No. 1 (2021)

Harrison, S.A. and Day, C.P. (2007).

Benefits of lifestyle modification in NAFLD. Gut., 56 (12):

1760-1769.

Hassanein, M.M.M. (2010).

Blending of roasted and unroasted sesame seeds oils with sunflower and olive oils for improving their antioxidation potency. Journal of Agricultural Chemistry and Biotechnology, 1 (8): 445-456.

Henry, R.J. (1974):

Creatinine measurements with colorimetric method. Clin. Chem., Principles and technics. $2^{\text {nd }}$ ed., Harper \& Row publishers, p: 525.

Kumar, M.C \& Singh, A.S. (2015).

Bioactive lignans from sesame (Sesamum indicum L.): evaluation of their antioxidant and antibacterial effects for food applications. J Food Sci Technol 52(5):2934-2941

Leite, N.C.; Salles, G.F.; Araujo. A.L.; Villela-Nogueira, C.A. and Cardoso, C.R. (2008).

Prevalence and associated factors of non-alcoholic fatty liver disease in patients with type-2 diabetes mellitus. Liver International., 29 (1): 113-119.

Oniga, L.; Pârvu, A.E.; Toiu, A. and Benedec, D. (2007).

Effects of salvia officinalis L. extract on experimental acute inflammation. Rev. Med. Chir. Soc. Med. Nat., 111: 290-294. 
Hadeer Ashraf Abd El-Aziz Abd El-Megeid, Seham A.M. Tharwat, Sonia S. El-Marasy and Ahmed E. Basyony.

Paglia, D.E. and Valentine, W.N. (1967).

Studies on the quantitative and qualitative characterization of erythrocyte glutathione peroxidase. J. Lab Clin. Med.;70(1):158-69.

Paniagua, J.A.; Sacristana, A.G.; Sanchez, E.; Romero, L. and Perez, F.A. (2007).

A MUFA-rich diet improves posprandial glucose, lipid and glp1 responses in insulin-resistant subjects. J. Am Coll Nutr., 26; 434-444.

SAS. (2004):

Statistical analysis system, SAS Users Guide : Statistics . SAS Institute Inc, Editors, Cary, NC

Sheehan, D. and Harpchak, B. (1980):

Phory and bractec histotechnology. $2^{\text {nd }}$ ed. Battle-Press, Ohio.

Shidfar, F.; Bahrololumi, S.S.; Doaei, S.; Mohammadzadeh, A.; Gholamalizadeh, M. and Mohammadimanesh, A. (2018).

The Effects of Extra Virgin Olive Oil on Alanine Aminotransferase, Aspartate Aminotransferase, and Ultrasonographic Indices of Hepatic Steatosis in Nonalcoholic Fatty Liver Disease Patients Undergoing Low Calorie Diet. Canadian Journal of Gastroenterology and Hepatology, Article ID 1053710: 1- 7. 
Egyptian J. of Nutrition Vol. XXXVI No. 1 (2021)

Son, D.S.; Parl, A.K.; MontgomeryRice, V.and Khabele, D. (2007). Keratinocyte chemoattractant $(K C) /$ human growth regulated oncogene (GRO) chemokines and proinflammatory chemokine networks in mouse and human ovarian epithelial cancer cells. Cancer Biology and Therapy 6:1302-1312.

Szende, B.; Timar, F. and hargitai, B. (1994).

Olive oil decreases liver damage in rats caused by carbon tetrachloride $\left(\mathrm{CCl}_{4}\right)$. Experimental and Toxicologic Patholigy; 46:355-359.

Taha, N.M.; Mandour, A.A.; Mohamed, M.K. and Emarha, T.R. (2014).

Effect of Sesame Oil on Serum and Liver Lipid Profile in Hyperlipidemic Rats. Alexandria J of Veterinary Sciences, 42: $17-25$

Tilg, H. and Moschen, A. (2010).

Weight loss: cornerstone in the treatment of non - alcoholic fatty liver disease. Minerva Gastroenterologica e Dietologica., 56 (2):159-167.

Tolman, K.G.; Fonseca, V.; Tan, M.H. and Dalpiaz, A. (2004).

Narrative review: hepatobiliary disease in type 2 diabetes mellitus. Ann Intern Med; 21:141:946-56.

Uthandi, A. and Ramasamy, K.(2011).

Hepatoprotective activity of sesame meal on high fat fed wistar rats. Inter J Pharm Sci and Res; 2(12):205-211 
Hadeer Ashraf Abd El-Aziz Abd El-Megeid, Seham A.M. Tharwat, Sonia S. El-Marasy and Ahmed E. Basyony.

Wilkins, T.; Tadkod, A.; Hepburn, I. And Schade, R.R. (2013).

Nonalcoholic Fatty Liver Disease: Diagnosis and Management. American Academy of Family Physicians., 88 (1):35-42.

Wu, T.; Tang, Q.; Zhuoping , G.; Song, H.; Zheng, X. and Chen, W. (2013).

Blueberry and Mulberry Juice Prevent Obesity Development in C57BL/6 Mice. PLOS ONE, 8 (10): 77-785.

Zarghani, S.S.; Soraya, H.; Zarei, L. and Alizadeh, M. (2016).

Comparison of Three Different Diet-Induced Non Alcoholic Fatty Liver Disease Protocols in Rats: A Pilot Study. Pharmaceutical Sciences, 22, 9-15. 
Egyptian J. of Nutrition Vol. XXXVI No. 1 (2021)

التأثيرات المحتملة لمسحوق المرمرية وزيوت السمسم والزيتون علي صورة الدهون ووظائف الكبد لفئران الكبد الدهنى غير الكحولي الكئي

\section{هدير اشرف عبد العزيز عبد المجيد* - سهام عباس محمود ثروث}

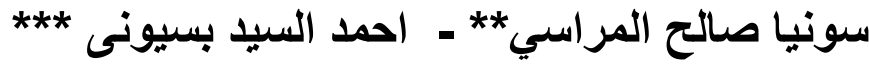

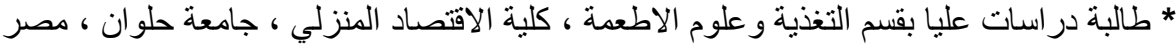

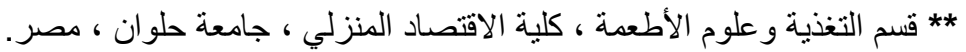

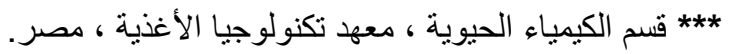

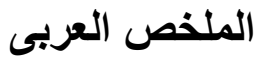

الهدف من هذه الدراسة هو معرفة تأثيرات المرمرية ، وزيوت (السمسم و الزيتون

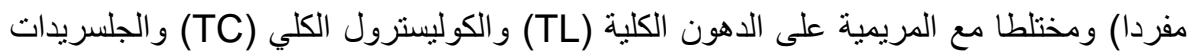

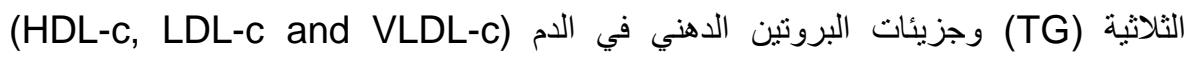
و إنزيمات الكبد والإنزيمات المضادة للأكسدة ، وكذلك التغيرات التيرات النسيجية للكبد في فئر ان الالبينو

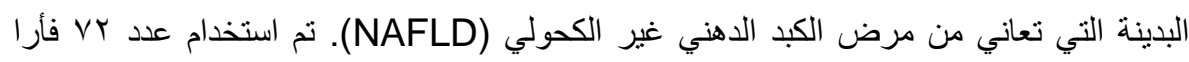

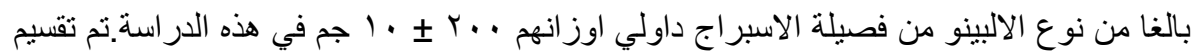

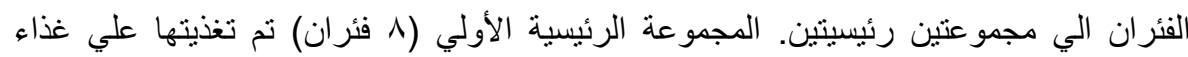

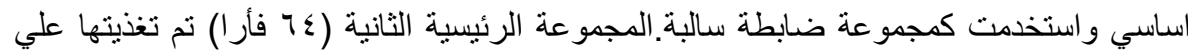

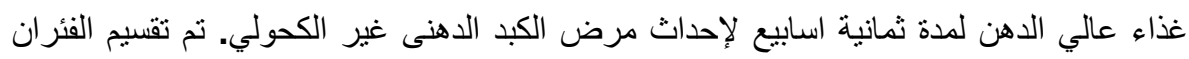

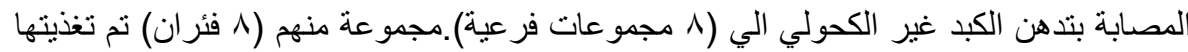

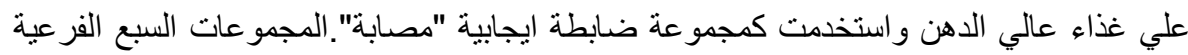

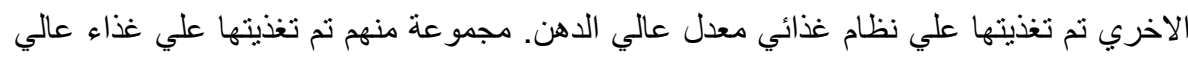

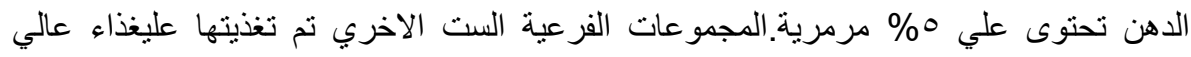

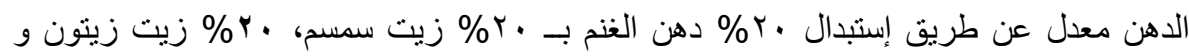


Hadeer Ashraf Abd El-Aziz Abd El-Megeid, Seham A.M. Tharwat, Sonia S. El-Marasy and Ahmed E. Basyony.

خليط " • (\% زيت سمسم مع · (\% زيت زيتون "بدون أو بإضافة المرمرية لمدة (1 اسابيع).

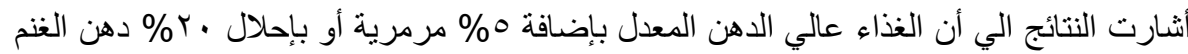

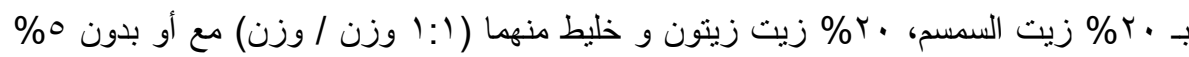

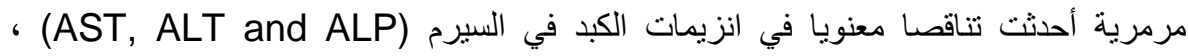
الكولسترول الكلي، الجلسريدات الثلاثية، كولسترول الليبوبروتينات منخفضة الكثافة والمنخفضة فئنة جدا، في حين أشارت النتائج الي حدوث ارتفاع معنوي في مستوى كولسترول الليبوبروتينات عالية الكثافة. أشارت النتائج أيضا الي حدوث ارتفاع معنوى التصائ حصائي في الانزيمات المضادة للأكسدة

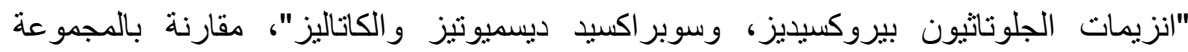

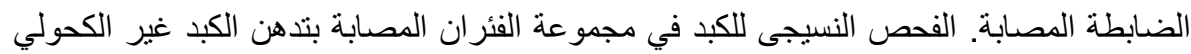

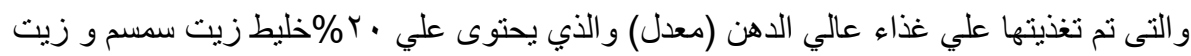

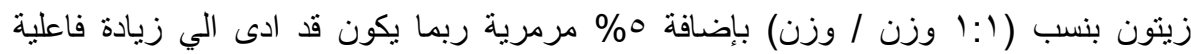

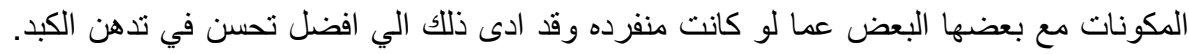

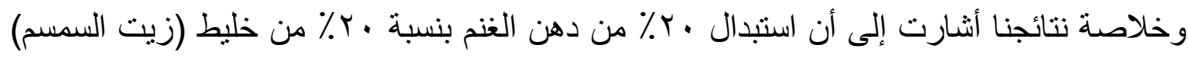

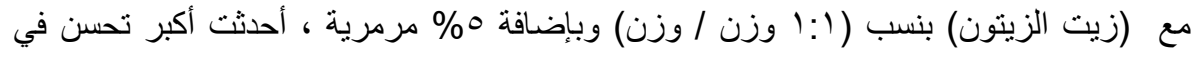

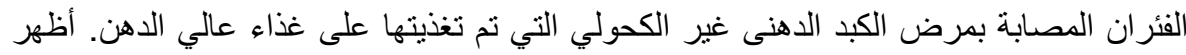

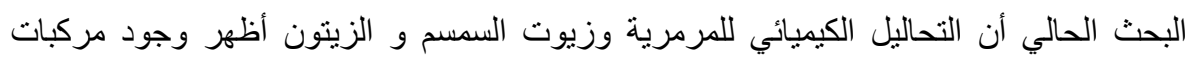
الفلافونويد والمركبات الفينولية وهذه المركبات لها قيمة علاجية ويمكن أن تعدل دهون الكبد وليد لمرضى السمنة المصابيين بتدهن الكبد. 